УДК: 54.062:615.243:547.773:543.544.5.068.7

DOI: 10.15587/2519-4852.2018.153387

\title{
DEVELOPMENT OF HPLC METHOD FOR QUANTITATIVE DETERMINATION OF NEW PERSPECTIVE APhI WITH ANTI-ULCER ACTIVITY OF TRIAZOPRAZOL
}

\author{
(C) N. Saidov, N. Smelova, N. Garna, O. Koretnik, N. Khanina, S. Gubar
}

Мета. Розробка оптимальної, високоточної, відтворюваної методики кількісного визначення основної речовини у субстанції триазопразолу методом високоефективної рідинної хроматографії.

Матеріали та методи. Для досягнення поставленої мети використовували фізико-хімічний (високоефективна рідинна хроматографія) та математичний (статистична обробка результатів) методи дослідження. Хроматографування проводили на рідинному хроматографi Agilent 1290 Infinity II з діодноматричним (LC 1290) детектором та квадрупольно-часпролітним (QTOF 6530) мас-детектором. Нерухома фаза: колонка хроматографічна 100×2,1 мм, заповнена силікагелем октадецилсилільним для хроматографії PZorbax Eclipse Plus C18, із розміром часток 3,5 мкм. Рухома фаза А: 0,1\% розчин мурашиної кислоти Р у воді Р. Рухома фаза В: 0,1 \% розчин мурашиної кислоти Р у ацетонітрилі Р. Швидкість потоку рухомої фази 0,6 мл/хв. Температура колонки $30{ }^{\circ} \mathrm{C}$. Об'єм інжекції 5 мкл. Детектор - діодноматричний (DAD). Детектування за довжини хвилі 248 нм. Налаштування детектора (Q-TOF): тип іонізаиії: позитивний, електроспрей (+ESI); режим вимірювання: сканування іонів з масою від 100 до 1000 а.о.; напруга на фрагментаторі: 100 B; температура азоту: $350{ }^{\circ} \mathrm{C}$; витрата азоту: 10 мл/хв; тиск небулайзеpa: 35 PSI; напруга на капілярі: 4 Кв. Хроматографічне розділення проводили при градієнтному елююванні на колониі, заповненій силікагелем октадецилсилільним.

Результати. Вміст діючої речовини у субстанції триазопразолу відповідав вимогам щзодо регламентованих меж кількісного вмісту. Тому запропонована методика може бути використана в прочесі фармацевтичної розробки та стандартизації лікарської форми. Крім того в умовах запропонованої методики визначенню діючої речовини не заважають ні розчинник, ні рухома фаза, щзо свідчить про специифічність методики.

Висновки. Вперие розроблена високоточна та відтворювана методика кількісного визначення основної речовини у субстанції триазопразолу методом високоефективної рідинної хроматографії.

Ключові слова. 1,2,4-триазолу, триазопразол, противиразкова активність, аналіз, кількісне визначення, метод ВЕРХ, діодно-матричний детектор.

\section{Introduction}

1,2,4-thiazole derivatives are characterized by low toxicity and high pharmacological activity [1,2], so they are widely used as drugs. There are such well known as Fluconazole, Thiotriazolin, Livel and other among these drugs [3]. Development and implementation of new 1,2,4-thiazole derivatives drugs is very promising direction. So it is necessary to develop methods, which will be used in the process of pharmaceutical development and standardization of appropriate dosage forms.
2. Formulation of the problem in general way, the relevance of the them and its connection with important scientific and practical issues

The substance 1 (4-methoxyanilide 5-(4methylphenylaminomethyl-4-(2-methylphenyl)-1,2,4triazole- $4 H-3$-ylthioglycolic acid has a high anti-ulcer activity $[4,5]$ and low toxicity according to the results of the pharmacological study. It was included into the plan of scientific developments by Company «Farmak» as Triazoprazole. That's why the development of an optimal, high-precision, reproducible method of standardizing the dosage forms of Triazoprazole is very relevant.<smiles>COc1ccc(NC(=O)CSc2nnc(CNc3ccc(C)cc3)n2-c2ccccc2C)cc1</smiles>

Fig. 1. (4-methoxyanilide 5-(4-methylphenylaminomethyl-4-(2-methylphenyl)-1,2,4-triazole-4H-3-ylthioglycolic acid (Triazoprazole) 
3. Analysis of recent studies and publications in which the solution of the problem is described and to with based the author refers

Scientists use a variety of physico-chemical methods, for the most part - variations of chromatographic for quantitative determination of 1,2,4-thiazole derivatives. The objects of the study were substances, dosage forms, body fluids and objects of the environment. Methods of determination of 1-methyl-1H-1,2,4-triazole by HPLC were offered in the works $[6,7]$. Determination was carried out in water samples and water extracts from the soil using HPLC with diode array detectors [6] and gas chromatography mass spectrometry [7].

The new method of quantitative determination of 1,2,4-triazole derivative namely 4-methyl-1-morpholinmethyl-2,4-dihydro-3H-1,2,4-triazole-3-thione, which demonstrates tuberculosis inhibition activity was developed [8]. Quantification was performed by reversed-phase highperformance liquid chromatography (RP-HPLC) using C18 column with a mobile phase consisting of methanol and water (5:95) at flow rate of $1 \mathrm{ml} / \mathrm{min}$. The chromatograms were recorded at $245 \mathrm{~nm}$ at $21^{\circ} \mathrm{C}$.

The retention behavior and separation ability of normal and reversed phase HPLC with one non-polar and two polar mobile phases, have been studied in work [9] by measuring the retention constants of a series of newly synthesized 1,2,4-triazole derivatives. The lipophilicity of new thiosemicarbazide and 1,2,4-triazole-3-thione derivatives was determined in work [10] using the RP-HPLC method, with the application of a mobile phase comprising methanol and water or acetonitrile and water.

The development and validation of HPLC-DMD method for intermediate products impurities determination of morpholinium2-((4-(2-methoxyphenyl)-5-(pyridine-4yl)-4H-1,2,4-triazole-3-yl)thio)acetate in bulk drug was described [11].

It was developed and validated method HPLC using electrospray tandem mass spectrometry for monitoring of content in the soil propiconazole and the product of its degradation - 1,2,4-triazole [12]. Excellent separations were achieved for propiconazole, tebuconazole and difenoconazole under a high-temperature high performance liquid chromatography on a carbon-clad zirconia column using water-rich eluent [13].

\section{The field of research considering the general problem, which is described in the article}

$\mathrm{SPhU}$ recommends using direct objective methods for quantitative determination of $\mathrm{APhI}$ which include, for example, titrimetric ones. So we have developed before for triazoprazole nitrogen determination in organic compounds after mineralization with sulfuric acid assay, which is described in a general monograph of SPhU 2.5.9 [14]. Metrological data of experimental results are given in the article [15].

But mentioned above method is unacceptable for dosage forms, because of excipients, which will interfere the determination. That is why determination was developed using the method of high performance liquid chromatography for the following pharmaceutical development.

\section{Formulation of goals (tasks) of article}

Development of method of quantitative determination of triazoprazole in substance using the method of high performance liquid chromatography.

6. Statement of the basic material of the study (methods and objects) with the justification of the results

Tests was conducted by liquid chromatography method in accordance with the requirements of the SPhU *, 2.2.29.

Test solution. $50 \mathrm{mg}$ (exact weight) of substances of triazoprazole transfer into a $100 \mathrm{~mL}$ flask, add $30 \mathrm{~mL}$ of methanol $R 2$, process for 5 minutes on an ultrasound bath until dissolved completely and dilute to $100 \mathrm{~mL}$ with methanol $R 2$, shake vigorously. $1.0 \mathrm{ml}$ of the getting solution transfer into a $50 \mathrm{~mL}$ flask, add methanol $R 2$ to $50 \mathrm{~mL}$ and shake. Filter through a membrane filter with a diameter of pores no more than $0.45 \mathrm{mkm}$.

Reference solution. $50 \mathrm{mg}$ (exact weight) $\mathrm{PhSS}$ of triazoprazole transfer into a $100 \mathrm{~mL}$ flask, add $30 \mathrm{~mL}$ of methanol R2, process for 5 minutes on an ultrasound bath until dissolved completely and dilute to $100 \mathrm{~mL}$ with methanol $R 2$, shake vigorously. $1.0 \mathrm{ml}$ of the getting solution transfer into a $50 \mathrm{~mL}$ flask, add methanol $R 2$ to $50 \mathrm{~mL}$ and shake. Filter through a membrane filter with a diameter of pores no more than $0.45 \mathrm{mkm}$.

All solutions are used freshly prepared.

Reference solution was chromatographed on a liquid chromatograph with a UV-detector and received from 2 to 6 chromatogram. Injection volume $5 \mathrm{mkl}$. Relative standard deviation (RSD) was calculated for peak areas from the obtained chromatograms. The obtaining of parallel chromatogram $\left(n_{0}\right)$ stopped when reaching requirements to $\mathrm{RSD}_{\max }$, which listed in the table 2.2.46-2 (SPU*, 2.2.46 ${ }^{N}$ ).

Test solution and reference solution was alternately chromatographed. The number of parallel chromatograms was obtained $(n)$ for each of the solutions not less when checking of suitability of the chromatographic system.

Chromatography conditions:

Liquid chromatograph Agilent 1290 Infinity II diode-array (LC 1290) detector and quadrupole-time-offlight (QTOF 6530) mass detector.

Fixed phase: chromatographic column $100 \times 2,1 \mathrm{~mm}$, filled with silica gel octadecylsilyl for chromatography $P$ Zorbax Eclipse Plus C18, with particle size $3,5 \mathrm{mkm}$.

Mobile phase A: $0.1 \%$ formic acid solution $R$ in water $R$;

Mobile phase B: $0.1 \%$ formic acid solution $R$ in acetonitrile $R$.

Flow rate of the mobile phase: $0.6 \mathrm{~mL} / \mathrm{min}$;

Temperature of the column: $30^{\circ} \mathrm{C}$;

Volume of the injection: $5 \mathrm{mkL}$;

Detector - diode-array (DAD);

Detecting: by wavelength $248 \mathrm{~nm}$. 
The gradient chromatographic program

\begin{tabular}{|c|c|c|}
\hline Chromatography time, $\min$ & MP A, \% & MP B, \% \\
\hline $0-32$ & $60 \rightarrow 30 \%$ & $40 \rightarrow 70 \%$ \\
\hline $32-35$ & $30 \%$ & $70 \%$ \\
\hline $35-36$ & $30 \rightarrow 60 \%$ & $70 \rightarrow 40 \%$ \\
\hline $36-40$ & $60 \%$ & $40 \%$ \\
\hline
\end{tabular}

Detector settings (Q-TOF):

$(+\mathrm{ESI})$

- type of ionization: positive, electrospray

- metering mode: scanning ion with a mass from

100 to $1000 \mathrm{u}$.;

- voltage on the fragmentator $100 \mathrm{~V}$;

- nitrogen temperature $350 \mathrm{C}$;

- nitrogen consumption $10 \mathrm{ml} / \mathrm{min}$;

- nebulizer pressure $35 \mathrm{PSI}$;

- voltage on the capillary $4 \mathrm{Kv}$.
Chromatographic system is considered fit if:

- efficiency of the chromatographic column, which is calculated at the main peak triazoprazole, must be no less than 5000 theoretical plates;

- coefficient of symmetry of the main peak triazoprazole reference solution (a) must be no less than 0,8 and no more than 1,5 ;

- relative standard deviation ( $\mathrm{RSD}, \%)$, which is calculated for the square of main peak of repeated chromatograms, should not exceed the value [340].

Table 2

Relative standard deviation value (RSD, \%)

\begin{tabular}{|c|c|c|c|c|c|c|c|}
\hline Number of parallel injections & 2 & 3 & 4 & 5 & 6 & 7 & 8 \\
\hline RSD, \% & 0.32 & 0.84 & 1.20 & 1.48 & 1.72 & 1.93 & 2.11 \\
\hline
\end{tabular}

The content of triazaprazole, is calculated by the formula, in percentages:

$$
X, \%=\frac{S \cdot m_{0} \cdot P \cdot 100 \cdot 50}{S_{0} \cdot m \cdot 100 \cdot 50}=\frac{S \cdot m_{0} \cdot P}{S_{0} \cdot m},
$$

where $\mathrm{S}$ - mid value of triasoprazole peak area, which is calculated from chromatograms of researched solution; $\mathrm{S}_{0}-$ mid value of triasoprazole peak area, which is calculated from chromatograms of reference solution; $\mathrm{m}$ - weight of the sample substance, $\mathrm{mg} ; \mathrm{m}_{0}$ - weight of triasoprazole, taken to prepare reference solution, $\mathrm{mg}$; $\mathrm{P}$ - the content of the main substance in triazaprazole, taken to prepare reference solution, $\%$.

Content of the triazoprazole in the substance of should be from $98,0 \%$ to $102,0 \%$ calculated on the anhydrous substance.

Results and discussion

The chromatographic separation was carried out with gradient elution using water with addition of $0.1 \%$ formic acid as a mobile phase $\mathrm{A}$ and acetonitrile with addition of $0.1 \%$ formic acid as a mobile phase $\mathrm{B}$ on a column filled with octadecylsil silica gel. Quantitative determination of the main substance was carried out in chromatographic conditions definition of the attendant adulterants of substances of triazoprazole, but at a wavelength of $248 \mathrm{~nm}$, where was a maximum absorption of the main substance.

By the proposed chromatographic conditions were achieved fulfillment of requirements $\mathrm{SPhU}$ to the characteristics of the main peak of triazoprazole reference solution with checking suitability of the chromatographic system. Terms gradient elution was chosen to separate peak the main substance and adulterants, as you can see on Fig. 2.

Solvent and mobile phase do not interfere in conditions of the proposed method for determining the active substance. It shows comparison of DAD- chromatograms (Fig. 2-4) and it demonstrates the specificity of the method.

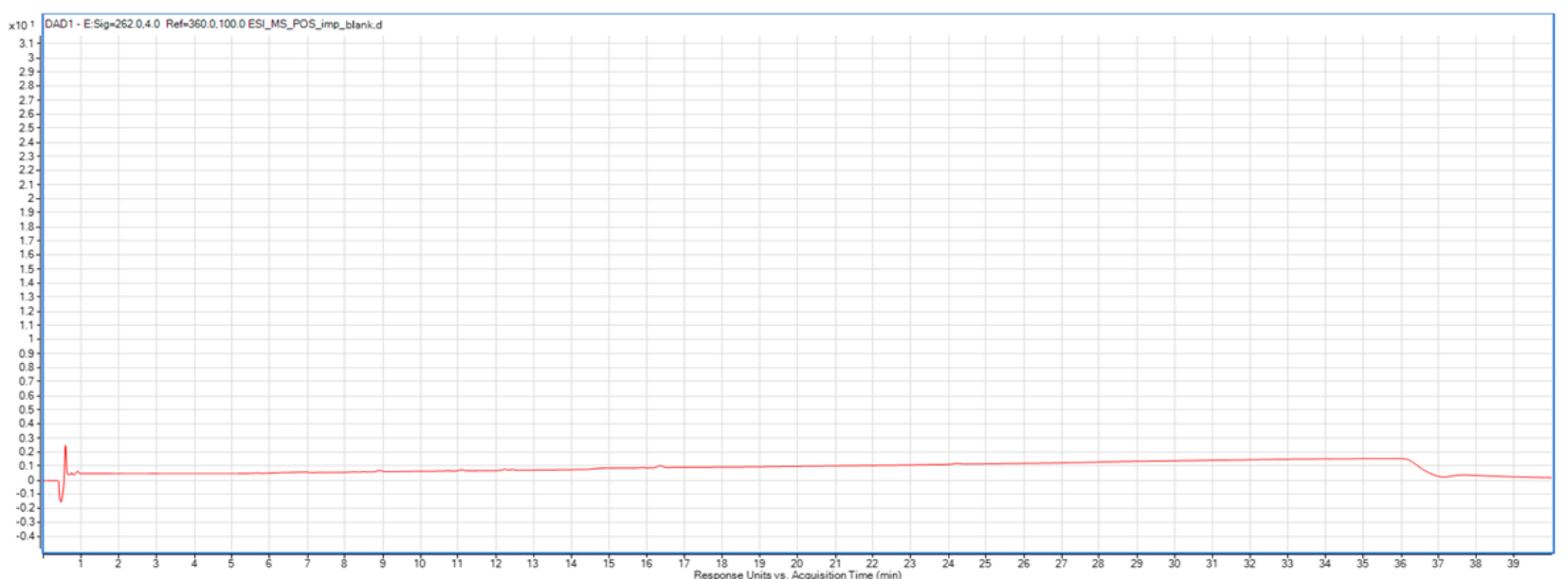

Fig. 2. The chromatogram of solvent (blank-chromatogram) 


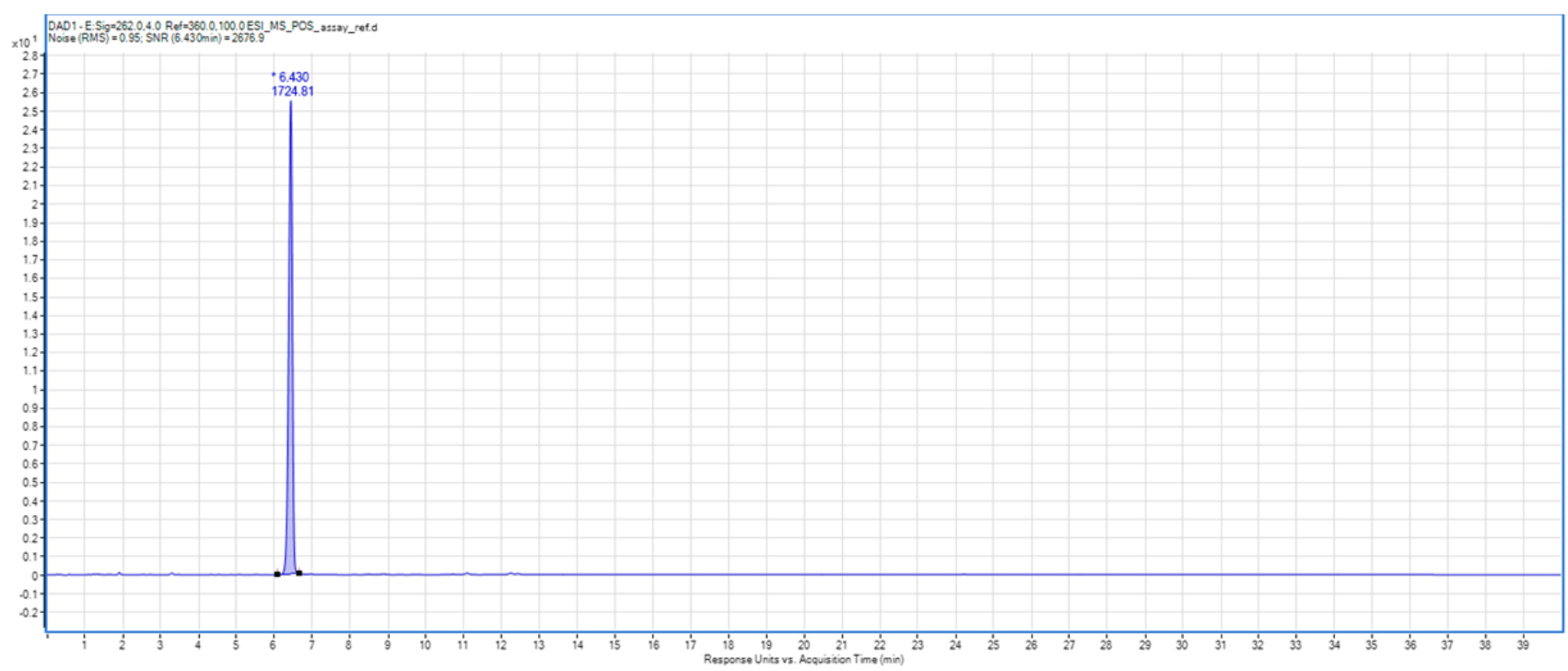

Fig. 3. The chromatogram of comparison solution

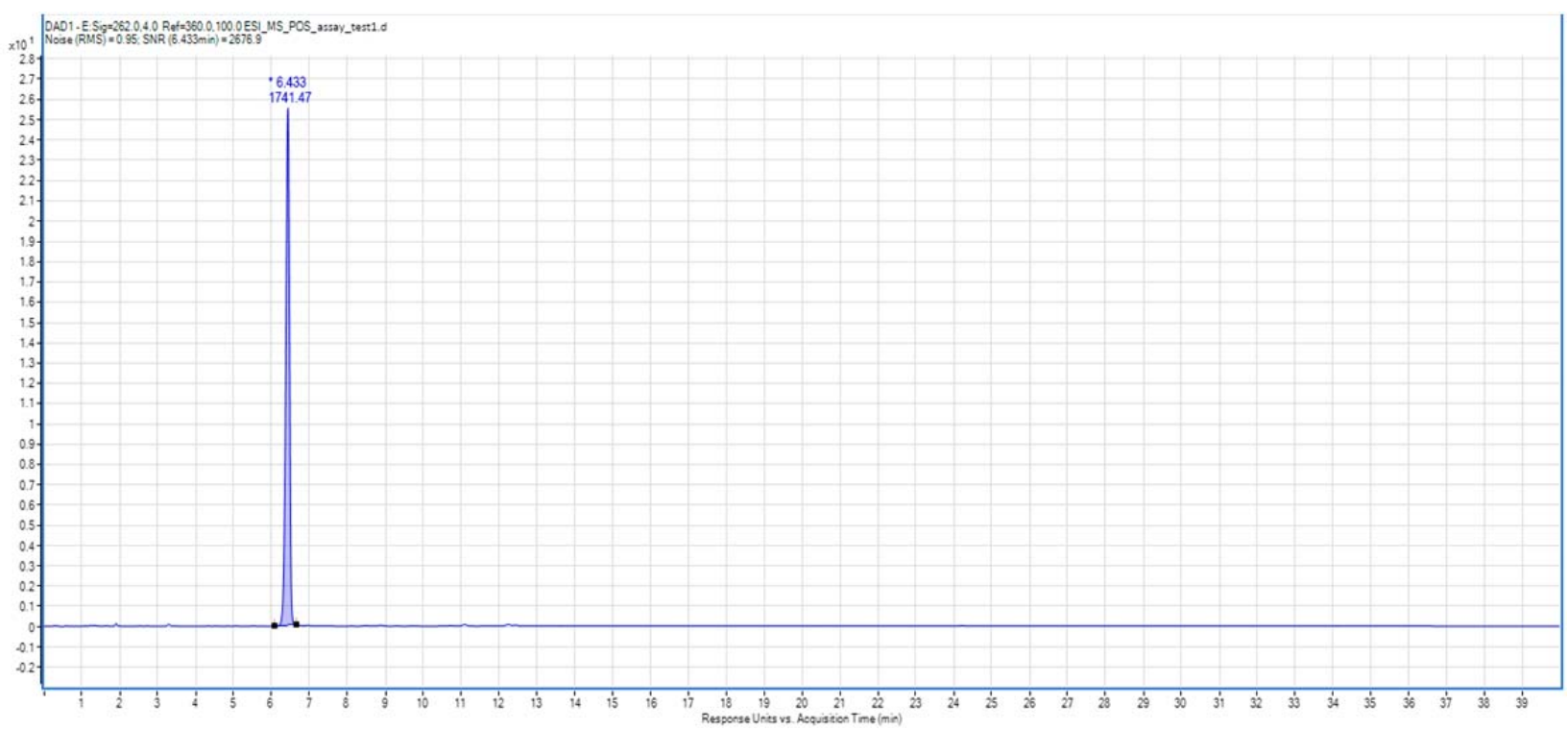

Fig. 4. The chromatogram of researched solution

The retention time peak of the main substance is about 6.43 minutes in the specified conditions (Fig. 3).

The symmetry coefficient of peak the main substance of triazoprazole is 0.97 , the column efficiency is 11843 of theoretical plates; relative standard deviation of 5 parallel injections of reference solution is 0.14 , which meets the requirements of suitability of the chromatographic system.

It was also obtained Q-TOF detector chromatograms in presented conditions of chromatography: mass spectrum of the triazoprazole basic substance (Fig. 5).

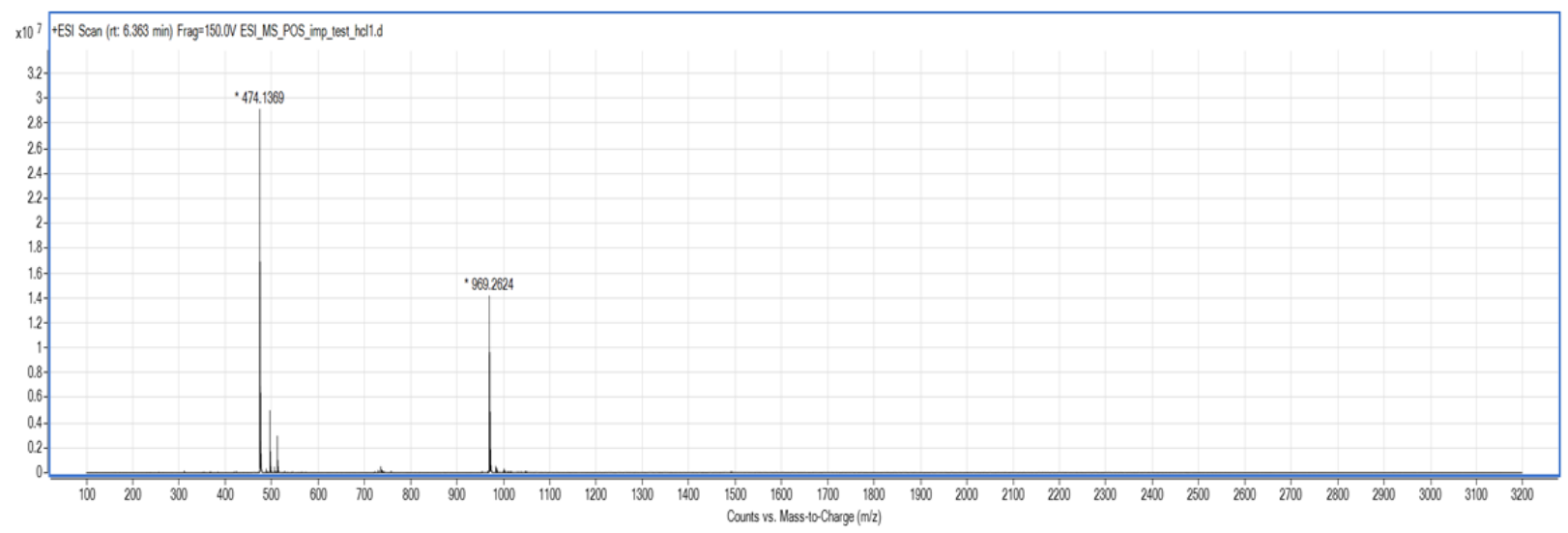

Fig. 5. Mass spectrum of the triazoprazole basic substance 
Quantitative content of triazoprazole in the substance was determined relative to squares of reference solution (Fig. 3). Calculation of quantitative content of triazoprazole in the substance is given in Table 3.
Metrological characteristics of average result of the quantitative determination of triazoprazole are given in Table 4.

Calculation of quantitative content of triazoprazole in the substance $(\mathrm{P}=99.4 \%)$

Table 3

\begin{tabular}{|c|c|c|}
\hline & Reference solution & Test solution \\
\hline \multirow{5}{*}{ Square of peaks } & 1724.81 & 1741.47 \\
\hline & 1727.33 & 1744.66 \\
\hline & 1724.13 & 1746.39 \\
\hline & 1728.54 & 1742.55 \\
\hline & 1729.89 & 1748.05 \\
\hline Average value & 1726.94 & 1744.62 \\
\hline $\mathrm{RSD}, \%$ & 0.14 & 0.15 \\
\hline Weight of the sample, mg & 49.8 & 50.3 \\
\hline Quantitative content, \% & & 99.42 \\
\hline
\end{tabular}

Table 4 Metrological characteristics of average result of the quantitative determination of triazoprazole $(\mathrm{P}=95 \%, \mathrm{t}(\mathrm{P}, \mathrm{v})=2.78)$

\begin{tabular}{|c|c|c|c|c|c|c|c|c|c|c|}
\hline$v$ & $X_{i}, \%$ & $\mathrm{X}_{\mathrm{cp},} \%$ & $\mathrm{~S}^{2}$ & $\mathrm{~S}_{\mathrm{cp}}$ & $\mathrm{P}$ & $\mathrm{t}(\mathrm{P}, v)$ & \multicolumn{3}{|c|}{ Confidence interval } & $\varepsilon, \%$ \\
\hline 1 & 2 & 3 & 4 & 5 & 6 & 7 & \multicolumn{3}{|c|}{8} & 9 \\
\hline \multirow{5}{*}{4} & 99.32 & \multirow{5}{*}{99.38} & \multirow{5}{*}{0.00315} & \multirow{5}{*}{0.025} & \multirow{5}{*}{0.95} & \multirow{5}{*}{2.78} & \multirow{5}{*}{$99.38 \%$} & \multirow{5}{*}{ \pm} & \multirow{5}{*}{0.070} & \multirow{5}{*}{0.070} \\
\hline & 99.42 & & & & & & & & & \\
\hline & 99.38 & & & & & & & & & \\
\hline & 99.33 & & & & & & & & & \\
\hline & 99.45 & & & & & & & & & \\
\hline
\end{tabular}

7. Conclusions from the conducted research and prospects for further development of this field

We can conclude that the content of active ingredient in the substance of triazoprazole meets the requirements of regulated limits of quantitative content according to the given data. The proposed method allows objectively evaluate the content of active ingredient in the substance of triazoprazole and can be used in the process of pharmaceutical development and standardization of the dosage form.

\section{References}

1. Kaur P., Chawla A. 1,2,4-Triazole: a review of pharmacological activities // International Research Journal of Pharmacy. 2017. Vol. 8, Issue 7. P. 10-29. doi: http://doi.org/10.7897/2230-8407.087112

2. Namratha B., Gaonkar S. 1,2,4-triazoles: Synthetic strategies and pharmacological // International Journal of Pharmacy and Pharmaceutical Sciences. 2014. Vol. 6, Issue 8. P. 73-80.

3. Remington - Essentials of Pharmaceutics / ed. by Felton L. A. Pharmaceutical Press, 2013. 772 p.

4. Synthesis, docking studies, and biological evaluation of anti-ulcer activity of 4-allyl-5-(4-R1)-phenylthiomethyl-1,2,4triazole-3-ylmercaptoacetic acid derivatives / Georgiyants V. et. al. // European Chemical Bulletin. 2014. Vol. 3, Issue 5. P. 466-471.

5. Zastosuvannia alkilovanykh pokhidnykh 1,2,4-tryazol-3-tiolu ta 1-fenil-1n-tetrazol-5-tiolu yak zasobu protyvyrazkovoi dii: Pat. No. 112867 UA. MPK: C07D 249/08 (2006.01), C07D 257/04, A61K 31/41, A61K 31/4196. / Georgiyants V., Severina G., Drogovoz S., Timofeev M., Saidov N., Kadamov I., Saaod Khaidar. No. u 2013 13290; declareted: 15.11.2013; published: 10.11.2016. Bul. No. 10.

6. Opredelenie 1-methyl-1H-1,2,4-triazole v vodnyih obraztsah metodom vyisokoeffektivnoy zhidkostnoy hromatografii s diodno-matrichnyim detektirovaniem / Kenesov B. et. al. // Habarshyi vestnik. Seriya himicheskaya. 2008. Vol. 1, Issue 49. P. 184-189.

7. Determination of 1-methyl- $1 \mathrm{H}-1,2,4$-triazole in soils contaminated by rocket fuel using solid-phase microextraction, isotope dilution and gas chromatography-mass spectrometry / Yegemova S. et. al. // Talanta. 2015. Vol. 143. P. 226-233. doi: http://doi.org/10.1016/j.talanta.2015.05.045

8. Isolation and Quantitative Determination of New Tuberculostatic 1,2,4-Triazole Derivative in Urine and Plasma Samples / Tatarczak-Michalewska M. et. al. // Journal of Analytical \& Bioanalytical Techniques. 2014. Vol. 5, Issue 4. doi: http://doi.org/10.4172/ 2155-9872.1000206

9. Acanski M., Perisic-Janjic N., Dimova V. Normal and reversed phase high performance liquid chromatography of some new 1, 2, 4-triazole derivatives // Acta Periodica Technologica. 2003. Vol. 34. P. 83-92. doi: http://doi.org/10.2298/apt0334083a 
10. Determination of Lipophilicity of New Thiosemicarbazide and 1,2,4-triazole-3-thione Derivatives Using Reversed-Phase HPLC Method and Theoretical Calculations / Hawryl A. et. al. // Journal of Liquid Chromatography \& Related Technologies. 2014. Vol. 38, Issue 4. P. 430-437. doi: http://doi.org/10.1080/10826076.2014.913519

11. Varynskyi B., Kaplaushenko A. The development and validation of HPLC-DMD method for intermediate products impurities determination of morpholinium2-((4-(2-methoxyphenyl)-5-(pyridine-4-yl)-4H-1,2,4-triazole-3-yl)thio)acetate in bulk drug // Zaporozhye Medical Journal. 2017. Vol. 9, Issue 3. P. 373-380. doi: http://doi.org/10.14739/2310-1210.2017.3.100947

12. Validation of an analytical method for 1,2,4-triazole in soil using liquid chromatography coupled to electrospray tandem mass spectrometry and monitoring of propiconazole degradation in a batch study / Blondel A. et. al. // Journal of Chromatography A. 2018. Vol. 1562. P. 123-127. doi: http://doi.org/10.1016/j.chroma.2018.05.056

13. High temperature high performance liquid chromatography of triazole fungicides on carbon-clad zirconia stationary phase / Sanagi M. et. al. // Malaysian Journal of Chemistry. 2004. Vol. 6, Issue 1, P. 55-66.

14. Derzhavna Pharmakopeya Ukrayini Vol. 1 / DP «Naukovo-ekspertniy farmakopeyniy tsentr». Kharkiv: DP «Ukrayinskiy naukoviy farmakopeyniy tsentr yakostI IIkarskih zasobIv», 2015. $1128 \mathrm{p}$.

15. Razrabotka metodiki kolichestvennogo opredeleniya potentsialnogo AFI s protivoyazvennyim deystviem / Saidov N. et. al. // Nauka i innovatsii. 2017. Vol. 4. P. 35-41.

Рекомендовано до публікації д-р фарм. наук Перехода Л. О. Дата надходження рукопису 06.11.2018

Narzullo Saidov, PhD, Associate Professor, Department of Pharmaceutical Chemistry, Tajik National University, Rudaki str., 17, Dushanbe, Tajikistan, 734025

E-mail: narzullos@mail.ru

Natalia Smelova, Director, Education and Research Training Center of Chromatographic Studies , National University of Pharmacy, Pushkinska str., 53, Kharkiv, Ukraine, 61002

E-mail: smelova08@gmail.com

Natalya Garna, PhD, Associate Professor, Department of Pharmaceutical Chemistry, National University of Pharmacy, Pushkinska str., 53, Kharkiv, Ukraine, 61002

E-mail: garnayan@ukr.net

Oksana Koretnik, PhD, Assistant, Department of Pharmaceutical Chemistry, National University of Pharmacy, Pushkinska str., 53, Kharkiv, Ukraine, 61002

E-mail: oksanakoretnik@gmail.com

Nataliia Khanina, Technician, Educational and Scientific Training Center for Chromatographic Studies, National University of Pharmacy, Pushkinska str., 53, Kharkiv, Ukraine, 61002

E-mail: lucky820.ua@gmail.com

Svetlana Gubar, PhD, Head of Laboratory, State Research Laboratory for Quality Control of Medicines, National University of Pharmacy, Pushkinska str., 53, Kharkiv, Ukraine, 61002

E-mail: gubarsn@ukr.net 